\title{
Spinal Meningocele
}

National Cancer Institute

\section{Source}

National Cancer Institute. Spinal Meningocele. NCI Thesaurus. Code C101209.

A cong enital abnormality in which the meninges protrude through a defect in the spinal column. 